Original Research Paper

\title{
Anti Fungi Potential of Psidium cattleianum afzel ex Sabin extraction as an inhibitor of fungi Fusarium solani
}

\author{
Lina Febriantini ${ }^{1}$, Khotibul Umam ${ }^{1 *}$, Putu Agus Hendra Wibawa ${ }^{2}$, Wawan Sujarwo ${ }^{2}$ \\ ${ }^{1}$ Fakultas Teknobiologi, Universitas Teknologi Sumbawa, Sumbawa, Indonesia; \\ ${ }^{2}$ Balai Konservasi Tumbuhan Kebun Raya, Lembaga Ilmu Pengetahuan Indonesia, Bali, Indonesia;
}

\begin{abstract}
Article History
Received : December 05 ${ }^{\text {th }}, 2021$

Revised : December 15 ${ }^{\text {th }}, 2021$

Accepted : December $25^{\text {th }}, 2021$

Published : January 05 ${ }^{\text {th }}, 2022$
\end{abstract}

\author{
*Corresponding Author: \\ Khotibul Umam, \\ Fakultas Teknobiologi, \\ Universitas Teknologi Sumbawa, \\ Sumbawa, Indonesia Email: \\ khotibul.umam@uts.ac.id
}

\begin{abstract}
The use of fungicides plays an important role in controlling plant diseases caused by Fusarium. However, the development of environment friendly fungicides is considered more effective, which used the plant secondary metabolites. This study aims to find the latest alternative fungicides using Psidium Cattleianum Afzel plant extract, ex Sabine from the collection of the "Eka Karya" LIPI-Bali Botanical Garden, which can inhibit the growth of $F$. solani and to find the minimum dose of the plant extract in inhibiting growth of $F$. solani. The method used was early screening of plant and fungi, medium preparation for fusarium and minimum dose analyze. This study found that based on 19 plants tested, Psidium cattleianum proved effective in inhibiting the $F$. solani. Further testing of psidium plants was carried out by looking at the minimum dose of inhibition against fusarium. The inhibition zone contained in the $1 \%$ treatment was greater than the concentrations of $0.75 \%, 0.50 \%$ and $0.25 \%$. The research was continued at a concentration reduction of $0.20-0.005 \%$ with the results showing that a concentration of $0.20 \%$ to a concentration of $0.05 \%$ resulted in a moderate inhibition zone of $8 \mathrm{~mm}$ to $9.2 \mathrm{~mm}$. Therefore, it can be concluded that the concentration of $1 \%$ is the concentration with the minimum dose of Psidium cattleianum in inhibiting the growth of the fungus Fusarium solani.
\end{abstract}

Keywords: Psidium Cattleianum Afzel, Ex Sabine, Fusarium solani, anti fungi, kebun raya Bali

\section{Pendahuluan}

Penyakit tanaman merupakan faktor penghambat utama pada produksi tanaman pertanian, terutama pada tanaman pangan dan holtikulltura (Kusmana \& Hikmat, 2015; Nuryanto, 2018). Penyakit tanaman disebabkan oleh banyak faktor namun salah satu diantaranya diantaranya disebabkan oleh jamur. Penggunaan fungisida berperan penting dalam pengendalian penyakit tanaman yang disebabkan jamur agar dapat mendukung produktivitas tanaman namun hingga kini belum memberikan hasil yang memuaskan (Diarta et al, 2016). Fungisida merupakan jenis pestisida yang secara khusus dibuat dan digunakan untuk membunuh dan menghambat pertumbuhan jamur patogen penyebab penyakit pada tanaman (Wahyuni et al., 2017). Pada dasarnya fungisida dibagi dalam dua kategori penggolongan, yaitu sistemik dan nonsistemik. Perbedaan antar keduanya adalah pada sistem penghambatannya (Pranoto et al., 2012).

Hasil penelitian yang dilakukan oleh (Wahyono dan Hartini, 1991) membuktikan bahwa penggunaan fungisida kimia mencemari lingkungan dan ekosistem disekitarnya, oleh karena itu penggunaan fungisida harus dikurangi untuk memininalisir terjadinya kerusakan yang ditimbulkannya. Salah satu alternatif pemanfaatan fungisida ramah lingkungan yakni melalui pemanfaatan metabolit sekunder tanaman untuk produksi biofungisida (Yusuf et al., 2016; Karlina et al., 2016; Pusztahelyi, 2015).

Tanaman Psidium Cattleianum Afzel, ex Sabine salah satu koleksi yang ada di Kebun 
Raya LIPI Bali memiliki potensi sebagai anti jamur setelah melalui skrining kemampuan metabolit sekunder pada beberapa jenis jamur. Menurut Askar et al (2020) penggunaan ekstrak tanaman yang telah melalui proses skrining untuk pathogen tertentu memiliki potensi dalam menghambat pertumbuhannya. Psidum cattleianum termasuk ke dalam family Myrtaceace dan secara umumnya jenis tanaman dalam family ini secara empiris digunakan oleh masyarakat sebagai obat (Renggana et al., 2018). Penggunaan tanaman Psidium yang digunakan sebagai biofungisida terhadap fusarium menjadi kabaharuan dari penelitian ini, karena belum ada riset serupa yang dilakukan. Oleh karenanya, penelitian ini bertujuan untuk mengetahui potensi ekstrak tanaman $P$. cattleianum terhadap jamur Fusarium solani yang biasanya menjadi penyebab terjadinya penyakit layu tanaman. Sehingga diharapkan adanya data penelitian ini dapat dimanfaatkan oleh masyarakat sebagai alternative fungisida dan menjadi referensi dalam penelitian terkait tanaman psidium.

\section{Bahan dan Metode}

\section{Waktu dan tempat penelitian}

Penelitian ini dilakukan pada bulan November 2018 hingga Januari 2019 bertempat di Kebun Raya Eka Karya LIPI - BALI pada Laboratorium Botani Terapan.

\section{Material Penelitian}

Bahan yang digunakan dalam penelitian ini yaitu: Material hidup 19 Tanaman terpilih koleksi Kebun Raya "Eka Karya" Bali tanaman dipaparkan pada Gambar 1. dan Tabel 1. Methanol, vaselin, etanol $96 \%$, alkohol $90 \%$, aquadest, media PDA, jamur Fusarium, fungsida kimia. Alat yang digunakan adalah : evaporator, Laminar air flow, kompor, gelas ukur,cawan petri, ose, tabung reaksi, ember plastik, pinset, jarum, gunting, pisau, tissue, gelas beker $1000 \mathrm{cc}$ dan 100 cc, mikropipet, mikrotube.

\section{Skrining dan ekstraksi sampel}

Proses skrining untuk memilih kandidat tanaman pada 19 famili Mirtaceae dilakukan dengan metode penelusuran literatur dan pengujian langsung ke tiga jeis jamur uji. Pada proses ekstraksi tanaman mengacu pada metode maserasi (Yulia et al 2020) sebanyak 100 gram tanaman segar diambil sesuai dengan bagian organ tanaman yang ingin diuji, untuk organ daun dicacah dengan ukuran sekitar $1 \mathrm{~cm}$, sedangkan untuk organ rhizome dipotong setipis mungkin. Material tanaman yang telah dicacah, dikering anginkan di dalam ruangan selama 3 - 6 hari, kemudian ditimbang berat keringnya. Sampel tanaman yang telah dikering anginkan kemudian dimaserasi menggunakan pelarut methanol dengan perbandingan 1 : 2 (sampai semua material terendam sempurna) dan direndam selama 24 - 72 jam kemudian disaring menggunakan kertas saring. Selanjutnya larutan ekstrak dimurnikan dengan menggunakan vacuum rotary evaporator dengan settingan suhu $45^{\circ} \mathrm{C}$. Proses evaporasi dihentikan jika larutan ekstrak telah mengental dan tidak ada tetesan metanol.

\section{Pembuatan media dan Pengujian awal}

Pembuatan media dilakukan dengan cara menimbang media sebanyak 19,5 gr, kemudian ditambahkan aquades sebanyak $500 \mathrm{ml}$. media dihomogenkan kemudian dipanaskan. Setelah itu media dituang kedalam tabung reaksi sebanyak $10 \mathrm{ml}$. Proses terakhir dari pembuatan media yaitu disterilisasi menggunakian autoclave dengan tekanan $2 \mathrm{~atm}$ dengan suhu $121^{\circ} \mathrm{C}$ selama 30 menit. Uji antijamur dilakukan dengan menggunakan metode disc diffusion assay (Daeng Pine et al., 2018). Uji antijamur awal ini dilakukan pada 19 tanaman skirining dengan pengujian 3 jamur (Aspergillus niger, Cholodosporium sp., dan Fusarim solani). Fusarium solani diremajakan pada PDA miring dan diinkubasi selama 7 hari pada suhu ruang. Pemanenan spora dilakukan dengan menggunakan jarum ose dengan dilarutkan ke dalam $10 \mathrm{~mL}$ air steril dan dihomogenkan. Dipipet sebanyak $200 \mu \mathrm{L}$ inoculan, dan dimasukkan kedalam cawan petri steril. Sebelumnya dipersiapkan media PDA cair dengan suhu kurang lebih $\left(45-50^{\circ} \mathrm{C}\right)$. Kemudian media PDA tersebut dituangkan ke dalam cawan petri berisi biakan, dihomogenkan, dan dibiarkan hingga membeku pada temperatur ruang. Setelah membeku, ambil Whatman paper disc diameter 6 $\mathrm{mm}$ yang dicelupkan ke dalam ekstrak beberapa menit kemudian diletakkan di tengah media, lalu ditutup kembali dan diinkubasi pada temperatur ruang selama 24 - 48 jam. Jamur patogen tanaman yang digunakan dalam penelitian ini ditunjukkan pada tabel berikut. 
Tabel 1. Daftar spesies jamur pathogen yang dijadikan sebagai kandidat penelitian

Spesies jamur patogenSumber isolate

Aspergillus niger Diisolat dari buah cabe busuk (capsicum annum)

Cholodosporium,sp. Diisolat dari tanah pertanian

Fusarium solani Diisolat dari buah cabe busuk (capsicum annum)

Ekstrak tanaman yang menunjukkan diameter daya hambat paling besar, akan di uji lebih lanjut untuk mengetahui dosis minimum dan kelarutan bahan aktifnya melalui proses fraksinasi.

\section{Pengujian dosis minimum}

Pengujian dosis minimum berdasarkan pada Salni et al (2013) dan askar et al (2020) yakni dengan pengenceran ekstrak dan penambahan methanol. Setiap konsentrasi ekstrak diuji efektifitasnya pada biakan jamur. Konsentrasi minimum adalah konsentrasi terendah dari ekstrak yang masih menunjukan daya hambat terhadap pertumbuhan jamur. Pengujian dilakukan 12 perlakuan konsentrasi dengan 3 kali ulangan. Adapun perlakuan dalam penelitian ini dapat dilihat pada (tabel 3). Pada pengujian ini, sebagai pembanding atau sebagai kontrol positif yaitu dengan pengujian dengan menggunakan fungisida kimia, dan sebagai kontrol negatif dilakukan pengujian terhadap methanol. Hal ini bertujuan untuk membandingkan apakah hasil uji ekstrak tanaman yang diuji lebih baik atau tidak. Sementra uji methanol bertujuan agar diketahui apakah methanol dapat mempengaruhi ekstrak dalam menghambat pertumnuhan jamur. Pemberian konsentrasi perlakuan bertujuan untuk mengetahui berapa dosis atau konsentrasi minimum dari ekstrak tanaman dalam menghambat jamur Fusarim solani. Pengujian antijamur dengan berbagai perlakuan konsentrasi dilakukan dengan metode yang sama seperti pada pengjujian antijamur diawal, perbedaannya hanya pada proses penetesan ekstrak.

\section{Analisis Data}

Analisis data dalam penelitian ini menggunakan perhitungan statistik dengan melihat standar eror dari hasil perhitungan microsoft excel (versi 2013). Selain itu, analisis data ini juga diperkuat dengan penggunaan analisis data one way ANOVA menggunakan aplikasi SPSS 16.0 untuk melihat perbandingan antara perlakuan ekstrak tanaman Psidium cattleianum dan kontrol positif yang digunakan dalam melakukan penghambatan terhadap jamur Fusarium solani.

\section{Hasil dan Pembahasan}

\section{Hasil Uji Skrining awal}

Pada penelitian ini telah dilakukan uji skirining awal pada 19 jenis tanaman dengan famili yang sama yaitu famili Myrtaceace. Banyak penelitian yang melaporkan bahwa tanaman pada famili myrtaceace memiliki kemampuan sebagai anti kanker (Renggana et al., 2018), antibakteri maupun anti fungi (Hariyati et al., 2015). Salah satu contoh jenis tanaman yang sering dilakukan dalam pengujian dari keluarga Myrtaceae yaitu Psidium Guajava Linn atau tanaman jambu biji (Nuryani, 2017). Daun Jambu biji telah banyak dimanfaatkan untuk mengobati diare, dan sakit kembung (Adnyana et al., 2004). Kandungan daun jambu biji adalah senyawa tanin 9-12\%, minyak atsiri, minyak lemak dan asam malat. Penelitian Claus dan Tyler, tanin mempunyai daya antiseptik yaitu mencegah kerusakan yang disebabkan bakteri atau jamur. Manfaat daun jambu biji (Psidium guajava L.) dibuktikan dapat mempercepat penyembuhan infeksi pada kulit yang biasanya di sebabkan oleh bakteri Staphylococcus aureus, Streptococcus spp, Escherichia coli, Salmonella typhi, Proteus mirabilis, dan Shigella dysenteria (Nuryani, 2017; Adnyana et al, 2004) Sehingga dalam penelitian ini dilakukan pengambilan jenis tanaman yang berbeda untuk diketahui bagaimana tingkat efektifitasnya.

Dalam penelitian ini dilakukan uji skrining awal dengan melakukan pengujian terhadap tiga jenis jamur yaitu jamur fusarium solani, jamur Cholodosforium, dan jamur Aspergillus niger. Pengujian tiga jenis jamur ini dilakukan untuk menguji 19 jenis tanaman untuk mengetahui jenis tanaman mana yang berpotensi dalam menghambat pertumbuhan ketiga jamur tersebut. yang efektif. tanaman yang memiliki kemamapuan positif menghambat. Namun dari 17 jenis tanaman tersebut Psidium Cattlenium merupakan satu satunya tanaman yang memiliki zona hambat yang positif terhadap jamur Fusarium solani yang dapat bertahan pada pengamatan $72 \mathrm{jam}$. 
Tabel 2. Skrining awal untuk pengujian zona hambat tanaman pada tiga jenis jamur berbeda yakni $F$. Solani, A. niger dan Cholodosporium.

\begin{tabular}{|c|c|c|c|}
\hline \multirow[b]{2}{*}{$\begin{array}{l}\text { Nama } \\
\text { spesies }\end{array}$} & \multicolumn{3}{|c|}{ INDIKASI ZONA HAMBAT } \\
\hline & $\begin{array}{l}\text { Fusarium } \\
\text { solani }\end{array}$ & $\begin{array}{c}\text { Aspergill } \\
\text { us } \\
\text { niger }\end{array}$ & $\begin{array}{c}\text { Cholodos } \\
\text { porium }\end{array}$ \\
\hline $\begin{array}{l}\text { Decaspermum } \\
\text { fruticosum }\end{array}$ & Positif & Negatif & Negatif \\
\hline $\begin{array}{l}\text { Psidium } \\
\text { guajava.L }\end{array}$ & Positif & Negatif & Negatif \\
\hline $\begin{array}{l}\text { oblongifolium } \\
\text { koord \& velton } \\
\text { (BALI) } \\
\text { E.20090911 }\end{array}$ & Positif & Negatif & Positif \\
\hline $\begin{array}{l}\text { Syzygium, sp. } \\
\text { NTT) } \\
\text { E.1999099 }\end{array}$ & Positif & Negatif & Negatif \\
\hline $\begin{array}{l}\text { Syzygium, sp. } \\
\text { Leptospermum } \\
\text { scoparium. }\end{array}$ & Positif & Negatif & Negatif \\
\hline $\begin{array}{l}\text { J.R } \\
\text { Foorts }\end{array}$ & Positif & Positif & Positif \\
\hline $\begin{array}{l}\text { \&.G..Fost } \\
\text { Syzygium, sp. } \\
\text { (SULTENG) }\end{array}$ & Positif & Positif & Negatif \\
\hline $\begin{array}{l}\text { Syzygium sp. } \\
134\end{array}$ & Negatif & Negatif & Negatif \\
\hline $\begin{array}{l}\text { Syzygium sp. } \\
28 \\
\text { Syzygium }\end{array}$ & Positif & Negatif & Positif \\
\hline$s p$. & Positif & Negatif & Negatif \\
\hline $\begin{array}{l}27 \\
\text { E.202912 } \\
\text { Syzygium }\end{array}$ & & & \\
\hline$s p$. & Positif & Negatif & Negatif \\
\hline $\begin{array}{l}291 \\
20 . E .2015060 \\
136\end{array}$ & & & \\
\hline $\begin{array}{l}\text { Syzygium sp. } \\
23\end{array}$ & Positif & Negatif & Positif \\
\hline $\begin{array}{l}\text { Syzygium } \\
\text { polyantum }\end{array}$ & Positif & Negatif & Positif \\
\hline $\begin{array}{l}\text { Eugenia } \\
\text { Uniflora L } \\
\text { Psidium } \\
\text { Cattleianum }\end{array}$ & Negatif & Negatif & Negatif \\
\hline $\begin{array}{l}\text { Afzel } \\
\text { ex.sabine./jep }\end{array}$ & Positif & Negatif & Negatif \\
\hline
\end{tabular}

\section{ang}

E.20070635

Syzygium

racemosum. Positif Negatif Negatif

$D C$

Syzygium $s p$. Positif Negatif Negatif

Byzygium $s p$. Positif Negatif Negatif

NTB Positif Negatif Negatif

Ammomum

maximum

(BALI)

E.19840332

Sementara untuk 18 jenis tanaman lainnya hanya bertahan pada pengamatan 24 jam hingga 48 jam. Tingkat pertahanan zona hambat yang dihasilkan berdasarkan kekuatan senyawa metabolit sekunder yang dihasilkan oleh suatu tanaman. Pada penelitian ini, tanaman Psidium cattleianum memiliki senyawa metabolit yang kuat sehingga mampu mengendalikan pertumbuhan jamur Fusarium solani. Penelitian yang dilakukan oleh Nuryani et al (2017) dari tanaman Psidium guajava menunjukkan hasil yang sama yakni kemampuan untuk menghambat C. albican dan $S$. aureus pada variasi konsentrasi yang beragam.

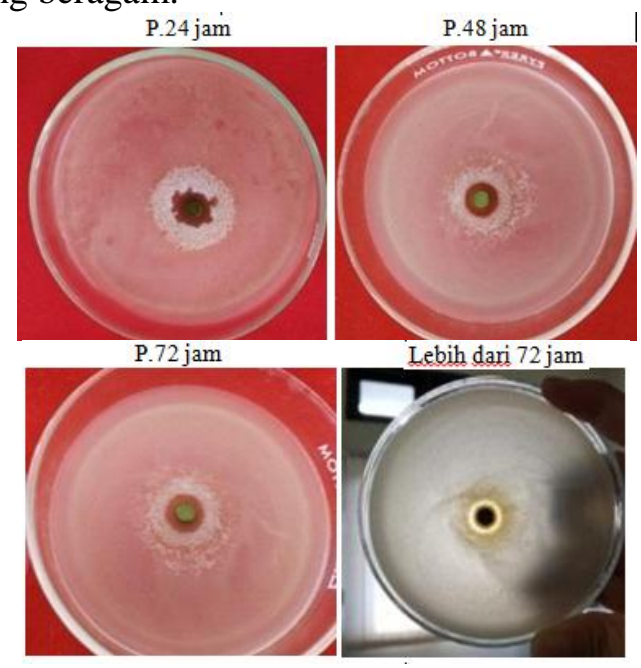

Gambar 1. Pengamatan hasil dari uji anti jamur dilihat dari zona bening yang terbentuk selama 24 jam sampai dengan $>72$ jam pada tanaman $P$. cattleianum

Hal ini menunjukkan bahwa psidium memiliki potensi untuk menghambat jamur dan bakteri.

Sedangkan pada tanaman lain hanya mampu menghambat pertumbuhan jamur namun 
tidak dapat mengendalikan pertumbuhan jamur Fusarium solani sehingga jamur dapat mengalami pertumbuhan lagi. Hal ini juga berhubungan dengan fase pertumbuhan jamur Fusarium solani yang mengalami fase pertumbuhan pada pengamatan 48 jam (Ngittu et al., 2014). Tanaman Psidium cattleianum ini dapat menekan atau mengendalikan pertumbuhan jamur bahkan pada fase pertumbuhan jamur pada pengamatan 48 jam. Sehingga tanaman Psidium catlleianum inilah yang diambil untuk dilakukan uji lanjutan untuk mengetahui dosis minimum yang dihasilkan.

\section{Uji dosis minimum daya hambat psidium Cattleianum}

Untuk mengetahui dosis minimum dari tanaman Psidium cattleianum ini dilakukan pengujian terhadap beberapa konsentrasi. Berdasarkan hasil pengamatan yang dilakukan parameter yang diamati yaitu mengamati tingkat zona hambat dari setiap perlakuan. Pengamatan aktivitas antijamur dilakukan dengan mengamati ada tidaknya zona hambat dan mengukur diameter zona hambat yang terbentuk dari tiga sisi kemudian dihitung rata-rata dari setiap perlakuan dan diukur setiap 24 jam (Salni et al, 2013; Askar et al, 2020).

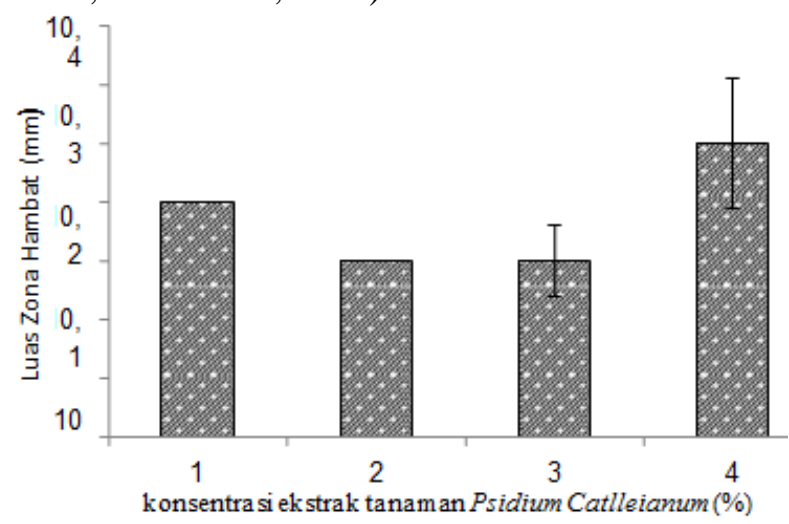

Gambar 2. Diagram pengujian konsentrasi awal tanaman Psidium catlleianum pada jamur $F$. Solani

Tingkat kepekatan sediaan yang dihasilkan dapat berpengaruh terhadap hasil uji yang dihasilkan. Sehingga dalam penelitian ini dilakukan beberapa pengenceran dengan konsentrasi yang berbeda untuk mengetahui berapa dosis minimum yang dihasilkan (Setyaningsih dan Sriwardani. 2005). Penelitian sebelumnya menunjukkan hasil yang sama untuk dosis minimum pada tanaman lengkuas (Salni et al, 2013); Montanoa (Askar et al, 2020); dan Jambu Bioa (Syarifah, 2006) dengan variasi dosis minimum yang digunakan untuk melihat kemampuan daya hambat tanaman.

\section{Uji dosis minimum P. cattleianum pada Penurunan Konsentrasi 1\%}

Pengujian dosis minimum dapat dilakukan dengan melakukan pengenceran terhadap ekstrak dengan cara penambahan metanol. Dalam penelitian ini ekstrak dengan konsentrasi terendah yaitu $1 \%$ diencerkan dengan penambahan metanol sebanyak $5 \mathrm{ml}$.

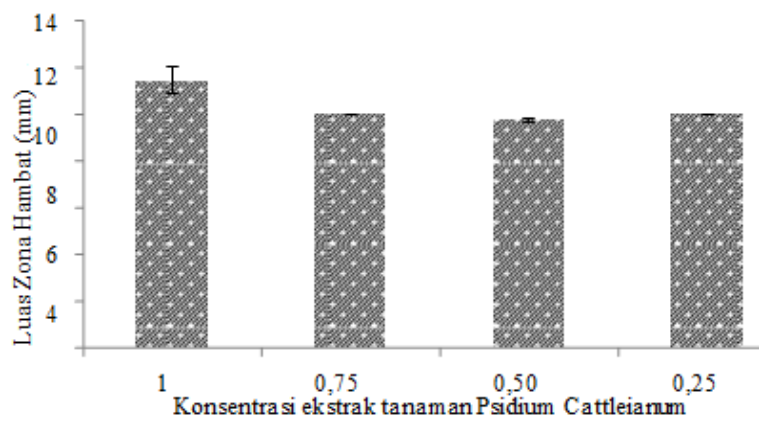

Gambar 3. Diagram luas zona hambat ekstrak tanaman Psidium cattleianum pada penurunan konsentrasi $1 \%$ pada jamur F.solani

Pada diagram diatas dapat diketahui bahwa hasil zona hambat yang terdapat pada perlakuan $1 \%$ lebih besar dibandingkan dengan konsentrasi $0,75 \%$, konsentrasi $0,50 \%$ dan konsentrasi 0,25 $\%$. Berdasarkan diagram diatas dapat juga diketahui bahwa konsentrasi ekstrak tanaman Psidium cattleianum berbanding lurus dengan zona hambat yang terbentuk. Pada konsentrasi 1 $\%$ merupakan tingkat zona hambat tertinggi yaitu 11,4 mm dan konsentrasi 0,75\% menghasilkan zona hambat yang tidak terlalu berbeda yaitu 10 $\mathrm{mm}$, sedangkan perlakuan $0,50 \%$ dan konsentrasi $0,25 \%$ memiliki tingkat zona hambat yang berbeda yaitu $9,7 \mathrm{~mm}$ dan $10 \mathrm{~mm}$. Pada konsentrasi 0,25\% masih menghasilkan zona hambat dengan kategori sedang yaitu $9,7 \mathrm{~mm}$, sehingga untuk mengetahui dosis minimum perlu dilakukannya penurunan konsentrasi dari $0,25 \%$ menjadi $0,20 \%$. Pengenceran dilakukan pada konsentrasi $0,25 \%$ dengan penambahan metanol sebanyak $2 \mathrm{ml}$. 


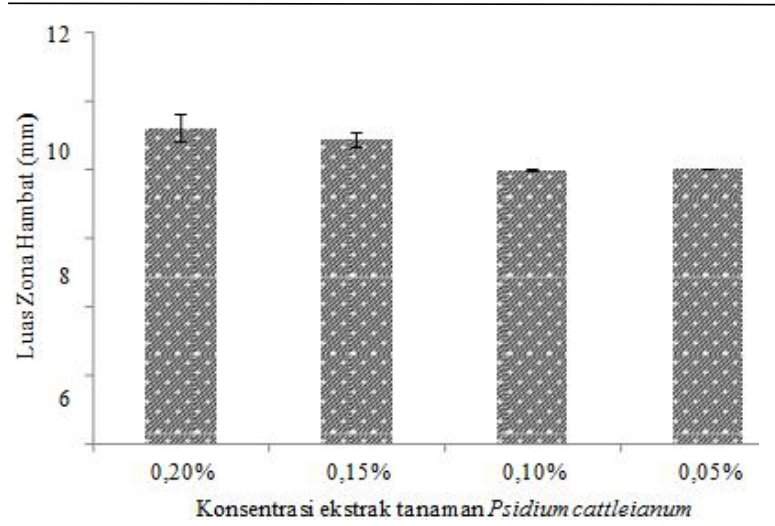

Gambar 4. Diagram luas zona hambat ekstrak tanaman Psidium cattleianum pada penurunan konsentrasi $0,25 \%$ pada jamur $F$. Solani

Berdasarkan Gambar tersebut dapat diketahui bahwa dari konsentrasi $0,20 \%$ hingga konsentrasi $0,05 \%$ menghasilkan diameter zona hambat dengan rentang yang sedikit yaitu $8 \mathrm{~mm}$ hingga 9,2 mm. Bahkan pada konsentrasi $0,10 \%$ dan $0,05 \%$ dengan penambahan metanol yang sama menghasilkan diameter zona hambat yang sama juga yaitu $8 \mathrm{~mm}$, sehingga dapat disimpulkan bahwa pada konsentrasi $1 \%$ merupakan konsentrasi dengan dosis minimum tanaman Psidium cattleianum dalam menghambat pertumbuhan jamur Fusarium solani. Pada hasil pengamatan rata-rata zona hambat yang telah dihitung, menunjukan bahwa konsentrasi $4 \%$ merupakan yang tertinggi menghasilkan zona hambat. Hal ini menjelaskan bahwa tingkat kepekatan suatu ekstrak dapat mempengaruhi dalam proses penghambatan jamur, sehingga menghasilkan tingkat zona hambat yang berbeda (Fardiansyah et al., 2020). Dalam penelitian ini pada perlakuan 3 dan 4 dengan konsentrasi $0,10 \%$ dan $0,05 \%$ terdapat zona hambat dengan rata-rata $8 \mathrm{~mm}$. Hal ini dikarenakan pada konsentrasi ini penambahan metanol yang diberikan sebanyak $25 \mathrm{ml}$ dan 50 $\mathrm{ml}$. Penambahan metanol yang banyak dapat mempengaruhi tingkat kepekatan dari suatu ekstrak. Pada penelitian ini, terlihat dari grafik bahwa dari perlakuan pengujian awal tidak memiliki rentang atau selisih rata - rata zona hambat yang tinggi. Sementara pada perlakuan $0,20 \%$ hingga perlakuan 0,05 rata-rata zona hambat yang dihasilkan yaitu sebesar $8 \mathrm{~mm}$ hingga $9 \mathrm{~mm}$. Menurut Rita, (2010) dalam Lingga et al (2015), bahwa dalam kekuatan zona hambat dapat dilihat dari tingkat rentang zona yang dihasilkan, rentang zona hambat dari 0

hingga $5 \mathrm{~mm}$ adalah zona hambat yang lemah, 5 $\mathrm{mm}$ hingga $8 \mathrm{~mm}$, sementara zona hambat dalam kategori kuat mulai dari $10 \mathrm{ml}$ hingga $20 \mathrm{ml}$. Sehingga pada konsentrasi $0,15 \%$ dan konsentrasi 0,05 menghasilkan zona hambat yang sedang karena masih dalam rentang $8 \mathrm{ml}$. Hal ini menunjukkan bahwa dosis minimum dari ekstrak Psidium Cattleianum dalam menghambat jamur Fusarium solani yaitu pada kosentrasi 0,25 $\%$ dengan luas zona hambat $10 \mathrm{~mm}$ dan termasuk ke dalam zona hambat yang kuat.

\section{Uji Efektifitas Tanaman Psidium cattleianum Afzel, ex Sabine Dalam Menghambat Jamur F.solani}

Efektivitas senyawa bioaktif tanaman Psidium cattleianum dalam menghambat petumbuhan jamur Fusarium solani dilakukan dalam 12 kelompok perlakuan dan penggunaan fungisida kimia sebagai kontrol positif. Dalam penelitian ini digunakan pengulangan sebanyak 3 kali untuk mendapatkan hasil yang akurat sehingga dapat membuktikan adanya pengaruh konsentrasi senyawa bioaktif tanaman Psidium cattleianum dalam menghambat pertumbuhan jamur F.solani. Pengujian efektivitas ini bertujuan untuk mengetahui efektivitas daya hambat dari senyawa bioaktif tanaman P. cattleianum terhadap jamur F. solani yang dibandingkan dengan kontrol positif. Penelitian ini menggunakan uji ANOVA (lampiran 6) dan uji lanjutan menggunakan Duncan Multiple Range Test (DMRT) dengan tingkat kepercayaan $95 \%$ (tabel 4.3). Hasil penelitian ini diperoleh dengan mengukur diameter zona hambat yang terbentuk disekitar paper disk dengan menggunakan penggaris dalam satuan $\mathrm{mm}$.

Tabel 3. Hasil uji Duncan Multiple Range Test (DMRT) (tingkat kepercayaan $95 \%$ ) terhadap luas zona hambat jamur Fusarium solani

\begin{tabular}{lll} 
No & Perlakuan & Rerata \\
\hline 1 & Konsentrasi 1\% & $10,00^{\mathrm{d}}$ \\
2 & Konsentrasi 2\% & $10,00^{\mathrm{d}}$ \\
3 & Konsentrasi 3\% & $9,33^{\mathrm{cd}}$ \\
4 & Konsentrasi 4 \% & $11,33^{\mathrm{e}}$ \\
5 & Konsentrasi 1 \% & $10,01^{\mathrm{a}}$ \\
6 & Konsentrasi 0,75 \% & $10,00^{\mathrm{d}}$
\end{tabular}




\begin{tabular}{lll}
\hline 7 & Konsentrasi 0,50 \% & $9,00^{\mathrm{bcd}}$ \\
8 & Konsentrasi 0,25 \% & $\mathbf{1 0 , 0 0}^{\mathbf{d}}$ \\
9 & Konsentrasi 0,20\% & $8,67^{\mathrm{abc}}$ \\
10 & Konsentrasi 0,15\% & $8,33^{\mathrm{abc}}$ \\
11 & Konsentrasi 0,10\% & $7,67^{\mathrm{a}}$ \\
12 & Konsentrasi 0,05\% & $8,00^{\mathrm{ab}}$ \\
13 & Kontrol Positif & $30,00^{\mathrm{f}}$ \\
& Konsentrasi 5,75 \%)* $^{*}$ \\
\hline
\end{tabular}

efektivitas setiap perlakuan tanaman Psidium cattleianum menunjukkan hasil yang berbeda jika dibandingkan dengan kontrol positif dalam menghambat pertumbuhan jamur F.solani. Tabel 4.3 menunjukkan bahwa hasil uji DMRT pada semua perlakuan yang diuji memberikan hasil yang berbeda nyata antar perlakuan yang ada. Hasil pengujian lanjutan DMRT menunjukkan bahwa terdapat perlakuan yang yang memiliki hasil yang hampir serupa dengan perlakuan kontrol positif yaitu perlakuan dengan konsentrasi Psidiun cattleianum $4 \quad \%$ pada perlakuan 5 yang menunjukkan angka $11,33 \mathrm{~mm}$. Perlakuan 5 merupakan hasil terbaik yang memiliki hasil serupa dengan kontol positif atau dikatakan menunjukkan hasil yang signifikan atau mendekati nilai pada control positif. Konsentrasi $4 \%$ dipilih sebagai perlakuan yang paling efektif karena jika dibandingkan dengan hasil uji awal pada jamur F.solani perlakuan ini menunjukkan hasil yang baik dalam menghasilkan zona hambat pada jamur F.solani. Daya hambat yang dihasilkan pada masing - masing konsentrasi menunjukkan bahwa zona hambat yang berbeda sesuai dengan peningkatan konsentrasi. Hal tersebut menunjukkan bahwa kemampuan antijamur dari senyawa bioaktif tanaman akan semakin tinggi pada konsentrasi yang tinggi pula dan akan berkurang dengan menurunnya konsentrasi senyawa bioaktif tanaman tersebut (Sinurat et al., 2018). Namun, hal tersebut tidak dengan produk fungisida kimia yang digunakan ssebagai kontrol positif. Pada kontrol positif menghasilkan zona hambat yang besar. Hal tersebut tersebut berbanding lurus dengan ekstrak tanaman Psidium cattleianum yang masih menunjukkan luas zona hambat pada konsentrasi $4 \%$, sehingga dapat dikatakan tanaman Psidium cattleianum ini efektif karena memiliki luas zona hambat yang kuat.

\section{Kesimpulan}

Penelitian ini membuktikan bahwa tanaman Psidium catleianum berpotensi dalam menghambat Fusarium solani berdasarkan hasil dari pengujian awal skrining tanaman. Selain itu, dikuatkan juga hasil tersebut dengan adanya variasi konsentrasi penambahan methanol atau dosis minimum berpengaruh pada pembentukan zona hambat yang dihasilkan dan efektivitas dalam penghambatan jamur F. solani. Semakin tinggi konsentrasi methanol maka semakin kecil zona hambat yang terbentuk, sedangkan konsentrasi ekstrak yang tinggi justru akan semakin tinggi pula efektifitas dalam menghambat jamur F. Solani. Selain itu dari semua perlakuan yang dilakukan diperoleh hasil bahwa konsentrasi minimum pada esktrak tanaman Psidium cattleianum lucudium adalah sebesar $0.25 \%$ dan masih termasuk dalam konsentrasi yang dapat menghambat jamur Fusarium Solani.

\section{Ucapan Terima Kasih}

Terima kasih disampaikan kepada fakultas Teknobiologi Universitas Teknologi Sumbawa yang telah memfasilitasi terlaksananya penelitian kerjasama dengan Kebun Raya Eka Karya , Bali. Tentunya dukungan dari seluruh pihak yang terlibat menjadi factor penyempurna dan terselesaikannya penelitian ini.

\section{Referensi}

Adnyana, I. K., Yulinah, E., Sigit, J. I., K, N. F., \& Insanu, M. (2004). Efek Ekstrak Daun Jambu Biji Daging Buah Putih dan Jambu Biji Daging Buah Merah Sebagai Antidiare Pendahuluan. Acta Pharmaceutica ITurcicaceutica Indonesia, XXIX(1), 19-27.

Daeng Pine, A. T., Azis, A., \& Darmawan, I. R. (2018). Potensi Krim Ekstrak Daun Johar (Cassia siame) Menghambat Pertumbuhan Candida albicans. Ad-Dawaa' Journal of Pharmaceutical Sciences, 1(1), 42-48. https://doi.org/10.24252/djps.v1i1.6439

Fardiansyah, A., Umam, K., Sujarwo, W., \& Hendra Wibawa, P. A. (2020). The Effectivity of Bioactive Compounds from Montanoa hibiscifolia Benth Plants in 
inhibiting the Growth of Candida albicans. Jurnal Biologi Tropis, 20(3), 460. https://doi.org/10.29303/jbt.v20i3.2174

Hariyati, T., Jekti, D. S. D., \& Andayani, Y. (2015). Pengaruh Ekstrak Etanol Daun Jambu Air (Syzygium Aqueum) Terhadap Bakteri Isolat Klinis. Jurnal Penelitian Pendidikan IPA, I(2). https://doi.org/10.29303/jppipa.v1i2.16

Karlina, Y., Adirestuti, P., Agustini, D. M., Fadhillah, N. L., Fauziyyah, N., \& Malita, D. (2016). Pengujian Potensi Antijamur Ekstrak Air Kayu Secang Terhadap Aspergillus niger dan Candida albicans. Chimica et Natura Acta, 4(2), 84. https://doi.org/10.24198/cna.v4.n2.10676

Kusmana, C., \& Hikmat, A. (2015). The Biodiversity of Flora in Indonesia. Journal of Natural Resources and Environmental Management, 5(2), 187-198. https://doi.org/10.19081/jpsl.5.2.187

Ngittu, Y. S., Mantiri, F. R., \& Tallei, T. E. (2014). Identifikasi Genus Jamur Fusarium Yang Menginfeksi Eceng Gondok (Eichhornia Crassipes) Di Danau Tondano. Pharmacon, 3(3), 156-161. https://doi.org/10.35799/pha.3.2014.5321

Nuryani, S. (2017). Pemanfaatan Ekstrak Daun Jambu Biji (Psidium guajava Linn) Sebagai Antibakteri dan Antifungi. Jurnal Teknologi Laboratorium, 6(2), 41. https://doi.org/10.29238/teknolabjournal. v6i2.95

Nuryanto, B. (2018). Pengendalian Penyakit Tanaman Padi Berwawasan Lingkungan Melalui Pengelolaan Komponen Epidemik. Jurnal Penelitian Dan Pengembangan Pertanian, 37(1), 1. https://doi.org/10.21082/jp3.v37n1.2018. p1-8
Pranoto, E., ruf, W., \& Pringgenies, D. (2012).

Kajian Aktivitas Bioaktif Ekstrak Teripang Pasir (Holothuria Scabra) Terhadap Jamur Candida Albicans. Jurnal Pengolahan Dan Bioteknologi Hasil Perikanan, 1(2), 1-8.

Renggana, H., Hadisaputri, Y. E., \& Subarnas, A. (2018). Jurnal Ilmiah Farmako Bahari Myrtaceae Anticancer Activities. Jurnal Ilmiah Farmako Bahari, 9(2), 23-32.

Rita, W. S. (2010). Isolasi, Identifikasi, dan Uji Aktivitas Antibakteri Senyawa Golongan Triterpenoid Pada Rimpang Temu Putih (Curcuma zedoaria (Berg) Roscoe). Jurnal Kimia, 4(1), 20-26.

Sinurat, A. P., Wina, E., Rakhmani, S. I. W., Wardhani, T., Haryati, T., \& Purwadaria, T. (2018). Bioactive substances of some herbals and their effectiveness as antioxidant, antibacteria and antifungi. Jurnal Ilmu Ternak Dan Veteriner, 23(1), 18.

https://doi.org/10.14334/jitv.v23i1.1660

Wahyuni, S., Nuryanti, S., \& Jura, M. R. (2017). Uji Daya Hambat Ekstrak Bawang Hutan (Eleutherine palmifolia (L.) merr) dari Matantimali Terhadap Pertumbuhan Jamur Candida albicans. Jurnal Akademika Kimia, 5(2), 98. https://doi.org/10.22487/j24775185.2016. v5.i2.8030

Yusuf, E. S., Nuryani, W., Djatnika, I., -, H., -, S., \& Winarto, B. (2016). Potensi Beberapa Fungisida Nabati dalam Mengendalikan Karat Putih (Puccinia horiana Henn.) dan Perbaikan Mutu Krisan. Jurnal Hortikultura, 22(4), 385. https://doi.org/10.21082/jhort.v22n4.2012 .p385-391 